\title{
Impact of Harvest Management on Forage Production and Nutrient Removal by Smooth Bromegrass on a Vegetated Treatment Area
}

\author{
R. Martine Similien' ${ }^{1}$ Todd P. Trooien ${ }^{2}$, Jixiang Wu${ }^{1}$, Arvid Boe ${ }^{*}$ \\ ${ }^{1}$ Departments of Plant Science, South Dakota State University, Brookings, SD, USA \\ ${ }^{2}$ Agricultural and Biosystems Engineering, South Dakota State University, Brookings, SD, USA \\ Email: ${ }^{*}$ arvid.boe@sdstate.edu
}

Received 25 May 2015; accepted 22 June 2015; published 25 June 2015

Copyright (C) 2015 by authors and Scientific Research Publishing Inc.

This work is licensed under the Creative Commons Attribution International License (CC BY). http://creativecommons.org/licenses/by/4.0/

\section{(c) (i) Open Access}

\begin{abstract}
Beef cattle (Bos taurus L.) feedlots pose serious environmental challenges associated with nutrient runoff. Smooth bromegrass (Bromus inermis Leyss.) is a perennial rhizomatous grass that is widely used for forage production in the USA and Canada. The objective of this research was to determine the best management system for producing forage from a vegetated treatment area (VTA) while maintaining the capacity of the VTA to remove nutrients from feedlot effluent. Four harvest management treatments (1-, 2-, and 3-harvest per year and an un-harvested control) were applied during spring 2005 and evaluated over a 5-yr period in a smooth brome sward on a VTA near Howard, SD. Mean annual total forage production during a 4-yr period ranged from $6.2 \mathrm{Mg} \cdot \mathrm{ha}^{-1}$ to $9.5 \mathrm{Mg} \cdot \mathrm{ha}^{-1}$ for 1- and 3-harvest systems, respectively. Nutrient removal by the bromegrass ranged from $148 \mathrm{~kg} \cdot \mathrm{N} \cdot \mathrm{ha}^{-1}$ and $15 \mathrm{~kg} \cdot \mathrm{P} \cdot \mathrm{ha}^{-1}$ for the 1-harvest treatment to $244 \mathrm{~kg} \cdot \mathrm{ha}^{-1} \mathrm{~N}$ and $24 \mathrm{~kg} \cdot \mathrm{ha}^{-1} \mathrm{P}$ for the 3-harvest treatment. Results indicated that high amounts of smooth bromegrass forage could be produced and soil nutrients removed from 2- and 3-harvest systems without compromising stand vigor and persistence on a VTA in eastern South Dakota.
\end{abstract}

\section{Keywords}

Forage Production, Harvest Management, Smooth Bromegrass

\footnotetext{
${ }^{*}$ Corresponding author.
}

How to cite this paper: Similien, R.M., Trooien, T.P., Wu, J.X. and Boe, A. (2015) Impact of Harvest Management on Forage Production and Nutrient Removal by Smooth Bromegrass on a Vegetated Treatment Area. American Journal of Plant Sciences, 6, 1550-1559. http://dx.doi.org/10.4236/ajps.2015.69154 


\section{Introduction}

Beef cattle (Bos taurus L.) feedlots are sources of nitrogen $(\mathrm{N})$, phosphorus (P), and other nutrients. If not properly controlled, these nutrients can contribute to the degradation of water quality in lakes, reservoirs, rivers, and ground water aquifers. Cattle manure contains appreciable amounts of $\mathrm{N}$ and $\mathrm{P}$, which can be transported from feedlots to receiving waters via runoff during precipitation events [1]. In 2003, the Environmental Protection Agency issued the Final Rule on Effluent Limitation Guidelines, which established collection pond technology as the standard for total animal waste containment [2]. However, the ruling also provided alternative technologies. One of the technologies being assessed as an option to treat livestock run-off is the vegetated treatment system (VTS) [3].

A typical VTS in South Dakota consists of a basin for solids separation and collection and a vegetated treatment area (VTA) for water and nutrient utilization. Types of VTAs include sloped VTAs, terraces, infiltration basins, and constructed wetlands. Vegetation may include aquatic plants, trees, and grasses grown for forage [4]. Vegetated treatment areas offer potential for production of high biomass and high quality forage. However, production of forage should not compromise their capacity to provide filtering for nutrients from feedlot effluent. Therefore, management strategies that permit high quality forage production while maintaining the filtering capacity of VTAs need to be developed [5].

The amount of soil nutrients absorbed by a forage crop mainly depends on soil nutrient availability, potential demand of the crop, and harvest strategy. Herbage $\mathrm{N}$ concentrations are generally higher under frequent harvest, because the plants are less mature at harvest, whereas the total $\mathrm{N}$ uptake could be higher or lower with frequent harvesting depending on species, soil, and year [6]. Singer and Moore [7] found that N and P concentrations decreased exponentially with increasing dry matter production at similar rates for different species of perennial grasses.

Nutrient removal efficiency increases with increased harvest intensity due to high $\mathrm{N}$ concentration at early plant developmental stages [6]. For $\mathrm{N}$ and $\mathrm{P}$, if the aim is to harvest maximum amounts of nutrients it is more important to achieve high dry matter production than a high concentration of nutrients [7]. In an integrated system for forage production and VTAs, the question is whether forage production or nutrient removal should be the main goal.

Grass swards and buffer strips can be used to reduce P losses. Used as buffer strips, grasses reduce P losses by reducing both total runoff and the suspended solids in runoff waters. Perennial grasses trap P from surface runoff by sedimentation of P-enriched soil particles and uptake of dissolved P [5] [8]. Grass species suitable for VTAs should have (i) potential for high biomass yield, (ii) tolerance for wet conditions, (iii) prolonged vegetative growth, and (iv) tolerance for more than one harvest per year. The first requirement is of importance for nutrient removal and the second for denitrification capacity. With a prolonged vegetative growth there is less risk of leaching during early spring and late autumn. Repeated harvest maintains active nutrient uptake by the crop and it also meets quality requirements on harvested biomass when using the grass as raw material for biogas generation [7].

Some perennial grasses that have been used with good results in wastewater treatment experiments and nutrient removal are reed canarygrass (Phalaris arundinacea L.), meadow foxtail (Alopecurus pratensis L.), switchgrass (Panicum virgatum L.), and smooth bromegrass (Bromus inermis Leyss.) (Figure 1). Grasses that are rhizomatous, have well-developed root systems, and can tolerate biannual harvesting for many years, have the possibility of producing high dry matter yields and may also have potential as energy crops [5]. Smooth bromegrass is used for hay and pasture throughout temperate North America [9]. It is an upright-growing perennial that spreads by rhizomes to produce a dense sod [10]. Vogel et al. [11] summarized results from harvest management studies on smooth bromegrass and concluded that forage yields are maximized when the first harvest is after heading and subsequent harvests are infrequent. Knievel et al. [12] found that the highest seasonal herbage yields and best stands of smooth bromegrass in Wisconsin occurred when the first crop was cut at early anthesis. Smith et al. [10] reported that stands of smooth bromegrass, growing with alfalfa, were nearly eliminated within three years when they were cut three times annually at a cutting height of $4 \mathrm{~cm}$.

Mixed biomass production with a VTA conservation practice could provide a "green" farming practice [13] to reuse manure nutrients from dairy manure, produce an alternative agricultural commodity, and protect the water resource in eastern South Dakota. Such herbage production systems may not only be environmentally sound for recycling of nutrients and minimizing nutrient loss to water bodies, but also help farmers/producers to maintain long-term economic profitability [5]. The objective of this research was to determine the best harvest management 


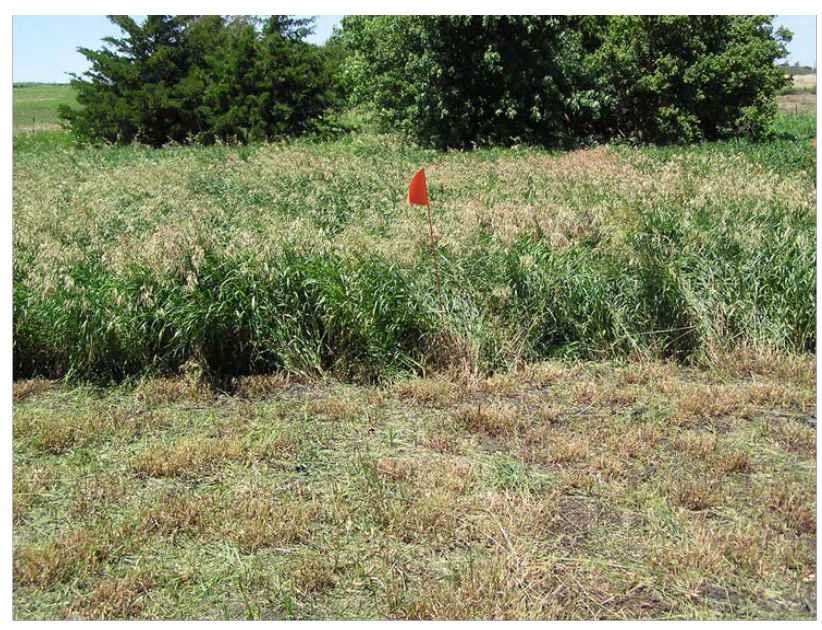

Figure 1. Smooth bromegrass near the bottom of the vegetated treatment area at peak standing crop on 1 July 2007.

system for high biomass production, stand persistence, high quality forage, and maximum nutrient (i.e., nitrogen and phosphorus) removal from a smooth bromegrass VTA for a beef cattle feedlot in eastern South Dakota.

\section{Materials and Methods}

An experiment was conducted from 2005 through 2009 at two landscape positions on a VTA near Howard $\left(44.006^{\circ} \mathrm{N}, 97.5140^{\circ} \mathrm{W}\right)$ in eastern South Dakota. The VTA area was approximately $8498 \mathrm{~m}^{2}$, with a relatively pure stand of smooth bromegrass with a $2 \%$ slope. The VTA aspect was to the east

(http://www2.ftw.nrcs.usda.govlosdldatlwiwentworth.html/6\17\2009). The soil on the VTA was a Clarno (Fineloamy, mixed, superactive, mesic Typic Haplustolls)-Bonilla (Fine-loamy, mixed, superactive, mesic Pachic Haplustolls) loam. The feedlot up slope from the VTA had an area of $50,586 \mathrm{~m}^{2}$, with a $4 \%$ slope. A gated pipe delivered effluent from the settling basin at the top of the VTA. The cumulative precipitations for each of 2005 through 2009 are presented in Table 1. Water and nutrient inflows and nutrient concentrations in the soil of the VTA are presented in Table 2. Methods used for runoff water collection and chemical analysis, soil sampling and soil nutrient analysis, and water and nutrient inflow and outflow measurements are described by Michael [14] and Ostrem [15].

An unknown cultivar of smooth bromegrass was seeded on the study site by the landowner several years prior to the initiation of the experiment and formed a nearly pure stand by the onset of this study. Prior to the experiment, the area had been lightly grazed or hayed, and no fertilizers or herbicides were applied.

Forage production and nutrient removal data collection began during 2005 and continued through 2009 on a relatively level area at the lowest region of the VTA near an outlet for surface runoff. Because there was no information for soil condition for the testing site, a Latin square experimental design at this landscape site was employed with four harvest management treatments. They included 1) control (not harvested until the end of the growing season during 2009); 2) one harvest (initial growth harvested at late anthesis/peak standing crop around July 1) per year, 3) two harvests (first harvest of initial growth at late anthesis around July 1 and second harvest of regrowth during autumn near end of growing season) per year, and 4) three harvests (initial growth at late anthesis around 1 July; second harvest when adequate regrowth was present, and third harvest, which was regrowth that accumulated between the second harvest during autumn near end of the growing season) per year (Table 3).

Dry matter (DM) yields were determined for each cutting and combined (in the case of 2- and 3-harvest treatments) to give treatment totals for each year. Individual plot size was $3 \times 3$ meters. The experiment was expanded during 2006 to include a second landscape position located in the upper region of the VTA about $10 \mathrm{~m}$ down slope of the gated pipe that carried effluent from the basin. This position had the same treatments and experimental design as the lower landscape position established during 2005 and was harvested during 2007 through 2009. The upper position had the four treatments and four replications randomized within rows parallel and within columns perpendicular to the gated pipe. 
Table 1. Precipitation totals (mm) for 2005, 2006, 2007, 2008, and the 30-yr average for Howard, SD (44.006 $\left.{ }^{\circ} \mathrm{N}, 97.514^{\circ} \mathrm{W}\right)$.

\begin{tabular}{cccc}
\hline & \multicolumn{2}{c}{ Period during year } \\
\hline Year & Jan-Mar & Apr-Sept & Oct-Dec \\
\hline 2005 & 37 & 594 & 153 \\
2006 & 50 & 498 & 56 \\
2007 & 135 & 356 & 127 \\
2008 & 41 & 362 & 187 \\
30-yr average & 70 & 442 & 91 \\
\hline
\end{tabular}

Table 2. Water and nutrient parameters for the smooth bromegrass VTA from 2005 through 2009.

\begin{tabular}{|c|c|c|c|c|c|c|}
\hline Year & $\begin{array}{l}\text { Monitoring } \\
\text { period }\end{array}$ & $\begin{array}{l}\text { Water inflow } \\
\quad(\mathrm{mm})\end{array}$ & $\begin{array}{l}\text { Nitrogen inflow } \\
\left(\mathrm{kg} \cdot \mathrm{ha}^{-1}\right)\end{array}$ & $\begin{array}{c}\text { Phosphorus inflow } \\
\left(\mathrm{kg} \cdot \mathrm{ha}^{-1}\right)\end{array}$ & $\begin{array}{l}\text { Soil nitrogen } \\
\left(\mathrm{kg} \cdot \mathrm{ha}^{-1}\right)^{\dagger}\end{array}$ & $\begin{array}{l}\text { Soil phosphorus } \\
\left(\mathrm{kg} \cdot \mathrm{ha}^{-1}\right)^{\dagger}\end{array}$ \\
\hline 2005 & 26 May-20 Oct & 331 & 614 & 164 & --- & --- \\
\hline 2006 & 9 May-16 Nov & 356 & 661 & 169 & 24,768 & 250 \\
\hline 2007 & 14 Mar-1 Sept & 1483 & 4229 & 876 & --- & --- \\
\hline 2008 & 11 Feb-3 Dec & 538 & 1043 & 299 & 26,492 & 383 \\
\hline 2009 & 23 Mar-30 Nov & 1026 & 2278 & 705 & --- & --- \\
\hline
\end{tabular}

${ }^{\dagger}$ Amount in the top $1.2 \mathrm{~m}$ of soil.

Table 3. Harvest dates for each of the harvest system treatments during 2005 through 2009 on a VTA near Howard, SD.

\begin{tabular}{|c|c|c|c|c|c|c|}
\hline & 2005 & 2006 & \multicolumn{2}{|c|}{2007} & 2008 & 2009 \\
\hline Harvest system ${ }^{\ddagger}$ & $\mathrm{L}$ & $\mathrm{L}$ & $\mathrm{L}$ & $\mathrm{U}$ & $\mathrm{L} / \mathrm{U}$ & $\mathrm{L} / \mathrm{U}$ \\
\hline Control & --- & --- & --- & --- & --- & 27 Oct. \\
\hline 1 & 1 July & 28 June & 27 June & 3 July & 2 July & 4 Aug. \\
\hline 2 & 1 July, 2 Oct. & 28 June, 26 Oct. & 27 June, 2 Nov. & 3 July, 2 Nov. & 2 July, 5 Nov. & 4 Aug., 27 Oct. \\
\hline 3 & $\begin{array}{c}1 \text { July, } 1 \text { Aug., } \\
2 \text { Oct. }\end{array}$ & $\begin{array}{l}28 \text { June, } 15 \text { Sept., } \\
26 \text { Oct. }\end{array}$ & $\begin{array}{l}27 \text { June, } 31 \text { Aug., } \\
2 \text { Nov. }\end{array}$ & $\begin{array}{c}3 \text { July, } 31 \text { Aug., } \\
2 \text { Nov. }\end{array}$ & $\begin{array}{l}2 \text { July, } \\
19 \text { Aug. }\end{array}$ & $\begin{array}{c}4 \text { Aug., } 7 \text { Sept., } \\
27 \text { Oct. }\end{array}$ \\
\hline
\end{tabular}

${ }^{\ddagger}$ No harvest taken on 5 Nov. due to insufficient regrowth after 19 Aug. harvest.

Plots were harvested at a cutting height of $7.5 \mathrm{~cm}$ with a rotary mower with a bagger. Fresh weights were taken in the field, and samples of approximately $1 \mathrm{~kg}$ were taken from harvested fresh biomass for each treatment and analyzed for DM, N, and P. Samples were first dried for $72 \mathrm{~h}$ at $60^{\circ} \mathrm{C}$ and ground to pass through a 1 $\mathrm{mm}$ screen. Total $\mathrm{N}$ concentration was determined by a modified Kjeldahl method (block digester). The same digest was used to determine total P with the molybdate-reactive method. In $20050.09 \mathrm{~m}^{-2}$ plots were harvested from each experimental unit regrowth in the 2- and 3-harvest systems to determine morphological differences between tillers from first and second regrowth cycles.

Mass of nitrogen removed was calculated as the product of forage dry matter yield and $\mathrm{N}$ concentration [7]. Crude protein concentration was determined by multiplying nitrogen concentration by 6.25 . Forage production and nutrient removal data were analyzed individually by year using the linear models procedure in Statistix 9 [16]. Harvest management treatments were considered a fixed effect. Our data analysis did not show significant row or column effects with this Latin square experimental design.

\section{Results}

\subsection{Forage Production}

The 2- and 3-harvest systems produced similar forage yields, which were significantly greater than the yields of 
the single harvest system for each of the five years. Grand means, averaged across years and landscape positions,

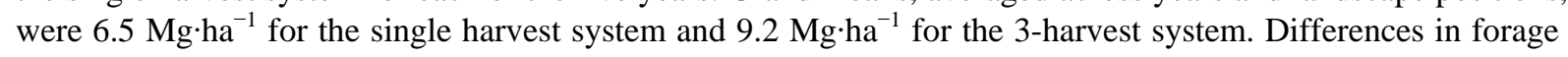
yield between single and multiple-harvest systems varied among years and ranged from $20 \%$ in 2007 (at bottom of VTA) and 2009 to $86 \%$ in 2006 (Table 4). The reason for regrowth composing considerably less of the total forage production in 2009 was due to the first harvest being delayed until early August due to wet soil conditions (Table 2 and Table 3). In general, the relative difference between the single- and multiple-harvest systems for forage yield appeared to be related to precipitation received during the growing season (i.e., April through September) (Table 1 and Table 3). The substantial inflow of water and nutrients to the VTA during 2007 occurred largely during late winter and early spring as a result of snowmelt. At that time the smooth bromegrass was not actively growing.

In 2008 precipitation during June was 120\% of normal, but July through August precipitation was only 46\% of normal (Table 1). Consequently, very little regrowth occurred after the second harvest of the 3-harvest system on 19 August 2008, and the second regrowth was insufficient to merit harvest in November (Table 3). In 2009, June through July precipitation was $140 \%$ of normal and water and nutrient inflows from the feedlot were substantial (Table 2).

A difference was found between landscape positions on the VTA for forage production in 2007, with the upper position near the gated pipe inflow producing $40 \%$ more forage than the position near the outlet of the VTA. However, no difference was found between landscape positions for forage production in 2008 and 2009. The landscape position $\mathrm{x}$ harvest treatment mean square was also non-significant; therefore, data were pooled across positions for the analysis of variance for each of 2008 and 2009 (Table 4).

Leaves tiller $^{-1}$ and individual tiller weight of regrowth were higher in a 2-harvest system than the second regrowth of the 3-harvest system. However, the leaf fraction was higher in the second regrowth of the 3-cut system (Table 5). Stockpiling regrowth for three months in the 2-harvest system provided high quality forage, with protein concentrations comparable to that of the shorter second regrowth regrowth cycle of the 3-harvest system. An example of the variation among initial and regrowth harvests for crude protein concentration is presented for 2007 in Table 6.

Table 4. Total dry matter forage production $\left(\mathrm{Mg} \cdot \mathrm{DM} \cdot \mathrm{ha}^{-1}\right)$ from four harvest treatments for 5 years for a smooth bromegrass vegetated treatment area (VTA) near Howard, SD. Identical experimental designs were located at the top of the VTA near the gated inflow pipe (U) and at the bottom of the VTA near an outlet for runoff (L). Data collection began for the lower experiment (L) in 2005 and for the upper experiment (U) in 2007.

\begin{tabular}{cccccccc}
\hline & 2005 & 2006 & & 2007 & 2008 & 2009 \\
\hline Harvest system $^{\ddagger}$ & $\mathrm{L}$ & $\mathrm{L}$ & $\mathrm{L}$ & $\mathrm{U}$ & $\mathrm{L} / \mathrm{U}$ & $\mathrm{L} / \mathrm{U}$ \\
\hline Control & --- & --- & -- & -- & -- & 7.5 \\
1 & 6.2 & 4.5 & 5.5 & 7.5 & 6.3 & 8.7 & 10.1 \\
2 & 10.5 & 8.2 & 6.1 & 9.5 & 10.1 & 8.6 & 10.6 \\
3 \\
LSD (0.05)
\end{tabular}

${ }^{\ddagger}$ Number of harvests during the growing season. Control plots were not harvested until the end of the growing season during 2009.

Table 5. Morphology of regrowth for smooth bromegrass near the bottom of a VTA at Howard, SD during 2005.

\begin{tabular}{ccccc}
\hline Harvest System & Regrowth period & Leaves $\cdot$ tiller $^{-1}$ & Tiller wt. (mg) & Leaf fraction \\
\hline 2 & 1 July to 2 Oct. & 6.5 & 496 & 0.62 \\
3 & 1 Aug. to 2 Oct. & 4.2 & 230 & 0.78 \\
F-test & & $* * *+*$ & $* *$ \\
\hline
\end{tabular}

${ }^{\dagger}$ Significant at the 0.01 level of probability. 
Table 6. Crude protein concentrations of initial growth and regrowth of smooth bromegrass near the top of a VTA near Howard, SD during 2007.

\begin{tabular}{cc}
\hline Duration of growth & $\mathrm{g} \cdot \mathrm{kg}^{-1}$ \\
\hline Up to 3 July & 156 \\
3 July to 31 Aug. & 271 \\
3 July to 2 Nov. & 245 \\
31 Aug. to 2 Nov. & 273 \\
LSD (0.05) & 29 \\
\hline
\end{tabular}

\subsection{Nutrient Removal}

Differences occurred among harvest systems for amounts of nutrients removed in harvested forage (Table 7 and Table 8). Nitrogen removal for the multiple harvest systems exceeded that of the single-harvest system by as little as 29\% in 2008 and by as much as 234\% in 2006 (Table 7). Similar trends occurred for removal of phosphorus by harvested forage (Table 8). Precipitation was well below normal in January through May 2006, and little runoff occurred. Most surface runoff occurred in August, September, and November when rainfall was much above normal (Table 1).

\section{Discussion}

\subsection{Forage Production}

This long-term study provided insight into the sustainability of multiple harvest systems for forage production from smooth bromegrass on VTAs in the northern Great Plains and provided new information for the region on the production potentials of 1-, 2- and 3-harvest systems for smooth bromegrass. Our results showed, averaged across five years, around $40 \%$ yield advantage to the multiple-harvest systems over the single-harvest system. They also indicated no advantage to a 3-harvest over a 2-harvest system for total annual forage production and no advantage of a single-harvest system over multiple-harvest systems for stand vigor and persistence when the first harvest was post-anthesis (i.e., during early July). In Saskatchewan, Canada a 2-cut system, with the first cut at full anthesis in mid-July, was more productive than a 3-cut system, with first cut at pre-anthesis in midJune, for smooth bromegrass on unfertilized soil [17]. Levels of forage production attained in this study are comparable to those reported for smooth bromegrass for a 5-yr study in Minnesota [18] and a 3-yr study in northeastern Nebraska [19].

Since, for the present study, the first harvest during each year was taken after anthesis, the most sensitive stage for harvesting initial growth of smooth bromegrass (i.e., jointing through heading) was avoided [11]. In this study, stands (data not shown) of multiple-harvest systems were maintained over the 5-yr period, and regrowth yields were related to the amount of precipitation received during mid-summer (Table 2 and Table 3 ). This indicated that the levels of water and nutrients applied from the feedlot runoff to the experimental areas of this study (Table 2) had little or no negative effect on stand density or persistence [20].

The regrowth fraction of total forage production (i.e., 30\%) for the present study was slightly higher than that reported from similar studies in the north central region of the USA. Under irrigation in western South Dakota, the first harvest at anthesis during mid-June of smooth bromegrass contributed $87 \%$ of the total forage production of a 2-harvest system with the second harvest taken during late August [21]. In a two-harvest system in western North Dakota on dryland, the first cutting of smooth bromegrass taken from mid-June to mid-August over a 5-yr period accounted for $80 \%$ of the total annual production [22]. Similar results were observed from a three-harvest system for smooth bromegrass in Wisconsin [23].

Similarly, taking the first harvest at early seed produced the highest forage yields in Saskatchewan [24]. In a 2-harvest system in Saskatchewan, McCartney et al. [6] found 76\% of the total production was from the first harvest taken during early July, with the second harvest occurring during late September. In Minnesota, forage yields of 2-harvest and 3-harvest systems, with first harvest at the green seed and heading stages, respectively, produced more forage annually over a 3-yr period than a 4-harvest system with the first harvest taken at boot stage [18]. 
Table 7. Total mass $\left(\mathrm{kg} \cdot \mathrm{ha}^{-1}\right)$ of nitrogen removed by forage from four harvest treatments for 5 years for a smooth bromegrass vegetated treatment area (VTA) near Howard, SD. Identical experimental designs were located at the top of the VTA near the gated inflow pipe (U) and at the bottom of the VTA near an outlet for runoff $(\mathrm{L})$. Data collection began for the lower experiment (L) in 2005 and for the upper experiment (U) in 2007.

\begin{tabular}{|c|c|c|c|c|c|c|}
\hline & 2005 & 2006 & & & 2008 & 2009 \\
\hline Harvest system & $\mathrm{L}$ & L & $\mathrm{L}$ & $\mathrm{U}$ & $\mathrm{L} / \mathrm{U}$ & $\mathrm{L} / \mathrm{U}$ \\
\hline Control & --- & --- & --- & --- & --- & 204 \\
\hline 1 & 131 & 83 & 132 & 186 & 160 & 199 \\
\hline 2 & 228 & 185 & 179 & 270 & 213 & 251 \\
\hline 3 & 227 & 204 & 206 & 311 & 241 & 274 \\
\hline LSD (0.05) & 5 & 9 & 24 & 43 & 35 & 24 \\
\hline
\end{tabular}

Table 8. Total mass $\left(\mathrm{kg} \cdot \mathrm{ha}^{-1}\right)$ of phosphorus removed by forage from four harvest treatments for 5 years for a smooth bromegrass vegetated treatment area (VTA) near Howard, SD. Identical experimental designs were located at the top of the VTA near the gated inflow pipe (U) and at the bottom of the VTA near an outlet for runoff (L). Data collection began for the lower experiment (L) in 2005 and for the upper experiment (U) in 2007.

\begin{tabular}{cccccccc}
\hline & 2005 & 2006 & & 2007 & & 2008 & 2009 \\
\hline Harvest system & L & L & L & U & L/U & L/U \\
\hline Control & --- & --- & --- & --- & -- & 16 \\
1 & 12 & 8 & 13 & 20 & 16 & 22 \\
2 & 21 & 18 & 17 & 28 & 32 & 22 & 29 \\
3 & 20 & 23 & 16 & 3 & 3 & 2 \\
\hline
\end{tabular}

Marten et al. [20] evaluated eight perennial forage species, including smooth bromegrass, under two levels of municipal wastewater effluent (i.e., 5 or $10 \mathrm{~cm} \cdot$ week $^{-1}$ ) and found that smooth bromegrass persisted better in 2-harvest than in 3- or 4-harvest plots. They attributed that difference to the stages of development at which the first harvest was taken. Plants were not fully headed for first harvest of the 3-harvest system and in the boot stage for the 4-harvest treatment. They concluded that smooth bromegrass did not persist sufficiently to receive consideration for forage production under the levels of effluent applied in their study.

\subsection{Nutrient Removal}

Nitrogen removal by forage varied with temporal environmental conditions that also influenced total forage production. Conditions that favored forage production during late summer and early autumn resulted in the highest nutrient uptakes. McCartney et al. [6] postulated that nutrient removal efficiency increases with increased harvest intensity due to high $\mathrm{N}$ concentration at early stages of plant development. In the current study, the second regrowth was comprised of almost entirely vegetative tillers with high $\mathrm{N}$ concentration.

Levels of nitrogen removal in this study were comparable to levels reported for smooth bromegrass in northern Saskatchewan [6]. In New Jersey, Singer and Moore [7] found nitrogen removal across N fertilizer rates varied greatly by year due to environmental conditions. They found in two consecutive years nitrogen removal from a 3-harvest system varied more than twofold, with about $400 \mathrm{~kg} \cdot \mathrm{N} \cdot \mathrm{ha}^{-1}$ removed during the most favorable year for plant growth. As was found in the present study, Singer and Moore [7] reported the greatest amount of nitrogen was removed in the first harvest. They also concluded that harvest interval and environmental conditions that favor vigorous growth promote increased nitrogen removal. For vigorous growth and nitrogen removal during autumn, they demonstrated the superiority of orchardgrass over smooth bromegrass. Similarly, Zemenchik and Albrecht [23] found orchardgrass, due to its more uniform seasonal yield distribution, to have higher apparent nitrogen recovery than smooth bromegrass. 
In general, $\mathrm{N}$ removal in the forage was not significantly different for the 2- and 3-harvest systems. However, the 3-harvest system removed more $\mathrm{N}$ than the 2-harvest system in 2006 and 2007. Phosphorus removal showed a similar pattern. The removal of $\mathrm{N}$ and $\mathrm{P}$ by the bromegrass forage was small relative to the amounts of each nutrient applied to the VTA from inflow. Undoubtedly, this high concentration of nutrients is related to the size of the area of the VTA, which was less than $20 \%$ of the area of the feedlot. In a solution-culture experiment, reed canarygrass (Phalaris arundinacea L.) and switchgrass (Panicum virgatum L.) were more effective than smooth bromegrass for removing excess $P$ from soil solutions [25].

In terms of forage quality, the second regrowth harvests were composed of vegetative growth with $>25 \%$ crude protein. In comparison, the crude protein concentration of the initial growth harvested near anthesis was about $150 \mathrm{~g} \cdot \mathrm{kg}^{-1}$, which exceeds maintenance requirements for most classes of livestock, including dairy cows. The regrowth forage, which far exceeded maintenance requirements for crude protein, could be blended with lower quality forages (i.e., crop residues) to extend forage supplies. However, the yield of the second regrowth was generally less than $1 \mathrm{Mg} \cdot \mathrm{ha}^{-1}$. Correspondingly, Zemenchik and Albrecht [23] concluded that the increase in forage $\mathrm{N}$ yield for three cool-season grasses was due to increased DM yield rather than an increase in $\mathrm{N}$ concentration in the forage tissues. The concentrations of crude protein found in the regrowth in this study were comparable to those reported by Smith and Sund [26] for vegetative regrowth of smooth bromegrass from Wisconsin.

An associated environmental benefit of using smooth bromegrass as opposed to orchardgrass (Dactylis glomerata L.), for example, for VTAs is the reduced potential for erosion provided by the extensive rhizome system of smooth bromegrass [27]. However, orchardgrass had higher apparent nitrogen recovery and higher nitrogen use efficiency due to a more uniform seasonal distribution of forage production than smooth bromegrass in Wisconsin.

Beef cattle feedlots have the potential to release high amounts of nitrogen and phosphorus to a VTA. The percentage of nitrogen recovered has been shown to be inversely related to the amount applied in fertilizer rate studies [7] [28]. Therefore, the size of the VTA, the size of the settling basin, which can influence the concentration of nutrients in the effluent applied to the VTA, and the nutrient uptake capacity of the vegetation are important parameters in the design of the vegetated treatment system. In the present study, the soil P level increased by $>50 \%$ over a 2-yr period; whereas, the soil $\mathrm{N}$ level increased by $<7 \%$. The amount of nitrogen in outflow was less than $1 \%$ (data not shown). The apparent loss of $\mathrm{N}$ from within the system may have been due to losses to the atmosphere through volatilization and leaching beyond the depth of soil sampling. Although the VTA was undersized, it appeared to be effective for containing nutrients [15].

\section{Conclusion}

Results of this research indicated that VTAs with a sod of smooth bromegrass could be managed (two to three harvests annually) sustainably to produce large amounts $\left(>8 \mathrm{Mg} \cdot \mathrm{DM} \cdot \mathrm{ha}^{-1}\right)$ of high quality forage and to remove high amounts of nutrients ( $\mathrm{N}$ and $\mathrm{P})$ from the soil. The quality of the forage produced on the VTA, estimated by concentration of crude protein (CP), was excellent. This capacity for high levels of quality forage production and nutrient removal was due to the ability of the smooth bromegrass to produce at least one cycle of leafy regrowth with a high concentration of $\mathrm{N}$ during the summer and early autumn, in addition to a large initial growth that reached physiological maturity during early summer. The sustainability of the 2- and 3-harvest systems may depend on the amount of precipitation that falls from the middle to the end of the growing season. Although this study indicated that smooth bromegrass was well-suited for vegetated treatment areas in South Dakota, future research that compares multiple species of perennial grasses in monoculture and mixtures for forage production and nutrient removal on vegetated treatment areas should be valuable.

\section{Acknowledgements}

This project was funded with grants from the Conservation Commission and from the EPA Section 319 program via South Dakota Department of Environment and Natural Resources. We are grateful to feedlot owner, John Reisch, feedlot manager Justin Feldhaus, and South Dakota State University Extension Educator Jim Krantz for their contributions to the project. We also thank Dr. Ron Gelderman and the staff of the South Dakota State University Soil and Plant Tissue Analysis Laboratory at South Dakota State University for the nitrogen and phosphorus determinations. 


\section{References}

[1] Sigua, G.C., Williams, M.J., Coleman, S.W. and Starks, R. (2006) Nitrogen and Phosphorus Status of Soils and Trophic State of Lakes Associated with Forage-Based Beef Cattle Operations in Florida. Journal of Environmental Quality, 35, 240-252. http://dx.doi.org/10.2134/jeq2005.0246

[2] EPA (2003) NPDES Permit Regulations and Effluent Limitations Guidelines for Confined Animal Feeding Operations. Factsheet No. EPA 821-F-03-003, Washington DC.

[3] Dosskey, M.G. (2002) Setting Priorities for Research on Pollution Reduction Functions of Agricultural Buffers. Environmental Management, 30, 641-650. http://dx.doi.org/10.1007/s00267-002-2755-y

[4] Berry, E.D., Woodbury, B.L., Nienaber, J.A., Eigenberg, R.A., Thurston, J.A. and Wells, J.E. (2007) Incidence and Persistence of Zoonotic Bacterial and Protozoan Pathogens in a Beef Cattle Feedlot Runoff Control-Vegetative Treatment System. Journal of Environmental Quality, 36, 1873-1882. http://dx.doi.org/10.2134/jeq2007.0100

[5] Pant, H.K., Adjei, M.B., Scholberg, J.M.S., Chambliss, C.G. and Rechcigl, J.E. (2004) Forage Production and Phosphorus Phytoremediation in Manure-Impacted Soils. Agronomy Journal, 96, 1780-1786. http://dx.doi.org/10.2134/agronj2004.1780

[6] McCartney, D.H., Bittman, S. and Nuttall, W.F. (2004) The Influence of Harvest Management and Fertilizer Application on Seasonal Yield, Crude Protein Concentration and N Offtake of Grasses in Northeast Saskatchewan. Canadian Journal of Plant Science, 84, 205-212. http://dx.doi.org/10.4141/P02-118

[7] Singer, J.W. and Moore, K.J. (2003) Nitrogen Removal by Orchardgrass and Smooth Bromegrass and Residual Soil Nitrate. Crop Science, 43, 1420-1426. http://dx.doi.org/10.2135/cropsci2003.1420

[8] Casler, M.D., Undersander, D.J. and Jokela, W.E. (2008) Divergent Selection for Phosphorus Concentration in Reed Canarygrass. Crop Science, 48, 119-126. http://dx.doi.org/10.2135/cropsci2007.03.0165

[9] Harrison, T. and Romo, J.T. (1994) Regrowth of Smooth Bromegrass (Bromus-Inermis Leyss) Following Defoliation. Canadian Journal of Plant Science, 74, 531-537. http://dx.doi.org/10.4141/cjps94-095

[10] Smith, D., Jacques, A.V.A. and Balasko, J.A. (1973) Persistence of Several Temperate Grasses Grown with Alfalfa and Harvested Two, Three, or Four Times Annually at Two Stubble Heights. Crop Science, 13, 553-556. http://dx.doi.org/10.2135/cropsci1973.0011183X001300050017x

[11] Vogel, K.P., Moore, K.J. and Moser, L.E. (1996) Bromegrasses. ASA, Madison.

[12] Knievel, D.P., Jacques, A.V.A. and Smith, D. (1971) Influence of Growth Stage and Stubble Height on Herbage Yields and Persistence of Smooth Bromegrass and Timothy. Agronomy Journal, 63, 430-434. http://dx.doi.org/10.2134/agronj1971.00021962006300030025x

[13] Sanderson, M.A., Jones, R.M., McFarland, M.J., Stroup, J., Reed, R.L. and Muir, J.P. (2001) Nutrient Movement and Removal in a Switchgrass Biomass-Filter Strip System Treated with Dairy Manure. Journal of Environmental Quality, 30, 210-216. http://dx.doi.org/10.2134/jeq2001.301210x

[14] Michael, N.O. (2007) Water and Nutrient Use Evaluation of South Dakota Vegetated Treatment Systems. M.S. Thesis, South Dakota State University, Brookings.

[15] Ostrem, D.T. (2010) Water and Nutrient Balances of Vegetative Treatment Systems for Feedlots in South Dakota. M.S. Thesis, South Dakota State University, Brookings.

[16] Statistix (2009) Statistix 9: Analytical Software. Tallahassee.

[17] Foster, A., Vera, C.L., Malhi, S.S. and Clarke, F.R. (2014) Forage Yield of Simple and Complex Grass-Legume Mixtures under Two Management Strategies. Canadian Journal of Plant Science, 94, 41-50. http://dx.doi.org/10.4141/cjps2013-095

[18] Marten, G.C. and Hovin, A.W. (1980) Harvest Schedule, Persistence, Yield, and Quality Interactions among Four Perennial Grasses. Agronomy Journal, 72, 378-387. http://dx.doi.org/10.2134/agronj1980.00021962007200020030x

[19] Rehm, G.W., Moline, W.J., Schwartz, E.J. and Moomaw, R.S. (1971) The Effect of Fertilization and Management on the Production of Bromegrass in Northeast Nebraska. Nebraska Agricultural Experimental Station Research Bulletin, 247, 27 p.

[20] Marten, G.C., Clapp, C.E. and Larson, W.E. (1979) Effects of Municipal Wastewater Effluent and Cutting Management on Persistence and Yield of Eight Perennial Forages. Agronomy Journal, 71, 650-658. http://dx.doi.org/10.2134/agronj1979.00021962007100040032x

[21] Johnson, J.R. and Nichols, J.T. (1969) Production, Crude Protein, and Use of 11 Irrigated Grasses and Alfalfa-Grass Combinations on Clay Soils in Western South Dakota. South Dakota Agricultural Experimental Station Bulletin, 555, 15 p.

[22] Berdahl, J.D., Karn, J.F. and Hendrickson, J.R. (2001) Dry Matter Yields of Cool-Season Grass Monocultures and 
Grass-Alfalfa Binary Mixtures. Agronomy Journal, 93, 463-467. http://dx.doi.org/10.2134/agronj2001.932463x

[23] Zemenchik, R.A. and Albrecht, K.A. (2002) Nitrogen Use Efficiency and Apparent Nitrogen Recovery of Kentucky Bluegrass, Smooth Bromegrass, and Orchardgrass. Agronomy Journal, 94, 421-428. http://dx.doi.org/10.2134/agronj2002.4210

[24] Lawrence, T. and Ashford, R. (1969) Effect of Stage and Height of Cutting on the Dry Matter Yield and Persistence of Intermediate Wheatgrass, Bromegrass, and Reed Canarygrass. Canadian Journal of Plant Science, 49, 321-332. http://dx.doi.org/10.4141/cjps69-054

[25] Kovar, J.L. and Claassen, N. (2009) Growth and Phosphorus Uptake of Three Riparian Grass Species. Agronomy Journal, 101, 1060-1067. http://dx.doi.org/10.2134/agronj2008.0088x

[26] Smith, D. and Sund, J.M. (1965) Nitrate in Forage, Influence of Stage of Growth and Soil Nitrogen on Nitrate Content of Herbage of Alfalfa, Red Clover, Ladino Clover, Trefoil, and Bromegrass. Journal of Agricultural and Food Chemistry, 13, 81-84. http://dx.doi.org/10.1021/jf60137a024

[27] Zemenchik, R.A., Wollenhaupt, N.C., Albrecht, K.A. and Bosworth, A.H. (1996) Runoff, Erosion, and Forage Production from Established Alfalfa and Smooth Bromegrass. Agronomy Journal, 88, 461-466. http://dx.doi.org/10.2134/agronj1996.00021962008800030017x

[28] George, J.R., Rhykerd, C.L., Noller, C.H., Dillon, J.E. and Burns, J.C. (1973) Effect of N Fertilization on Dry Matter Yield, Total-N, N Recovery, and Nitrate-N Concentration of Three Cool-Season Forage Grass Species. Agronomy Journal, 65, 211-216. http://dx.doi.org/10.2134/agronj1973.00021962006500020008x 